\title{
CAUSES FOR THE CHANGE ORDERS IN ROAD CONSTRUCTION: REVIEWED FROM OWNER
}

\author{
Mega Waty*, Hendrik Sulistio \\ Civil Engineering Program, Tarumanagara University, Jakarta, Indonesia \\ *E-mail of corresponding author: mega@ft.untar.ac.id
}

\section{Resume}

Changes in road construction are affected by the owner and contractor at the beginning, middle, or end of the project. This study aims to determine the ranking of the factors that cause change orders for road construction from the owner's point of view. Data was collected by distributing questionnaires and interviews to project owners. Reliability and validity tests involving 32 respondents resulted in 48 causes of change orders. This study quantifies the relative importance of the factors that cause change orders and shows the ranking of factors and groups that cause change orders according to their level of importance for causes of change orders. This goal is achieved through the analysis of the results of the interviews. According to the calculation of the Relative Importance Index (RII), all the factors and groups are ranked and the most significant ranking is determined regarding the causes of the change orders.

\section{Article info}

Received 6 October 2021

Accepted 6 December 2021

Online 26 January 2022

\section{Keywords:}

rank cause change order relative importance index owner

ISSN 1335-4205 (print version) ISSN 2585-7878 (online version)

\section{Introduction}

There is a need for traffic engineering to optimally utilize the road network to reduce the congestion resulting from inadequate mass public transport. One way to improve the traffic engineering is building the transportation facilities through the road construction and improvement. Road construction involves changes by owners and contractors at the beginning, middle, or the end of the project.

A change order $(\mathrm{CO})$ is a written agreement to modify, add, or provide alternatives to the work regulated in the contract document between the owner and a contractor. The change could be included in the original project scope when the contract involves modification (Fisk, 2010) [1]. In addition, a change order is an event due to the job modification resulting in time and cost alterations during the project implementation [2]. Change orders are common in construction projects, often increasing the contract price by $5-10 \%$, [3]. Definitively, change orders are documents issued to accommodate the additional work in a contract due to design errors, unexpected site and weather conditions and bidding characteristics, [4]. Change orders are among the most significant problems facing the construction industry, especially during the construction , [5]. These orders comprise work changes after the owner and contractor sign the contract at the beginning, middle, or the end of the project. Moreover, the orders are common in government and private construction projects from the contractor and the owner's perspective [6]. Changes in construction projects are unavoidable [7], increasing the price of contract items [3] and causing the project delays [8]. Akhavian and Behzadan [9] stated that the construction industry in the United States spends more than $\$ 60$ billion per year on change orders. In line with this, a new highway construction project in Kentucky found that $61 \%$ of projects experienced change orders due to contract negligence [10]. Furthermore, a study examined the data for 614 road maintenance projects performed by the Kenya Rural Road Authority. The results showed that change orders increased project costs by $13.07 \%$ [11]. Halwatura and Ranasinghe [12] identified 55 main causes of change orders for the road construction projects in Sri Lanka. The top five causes were poor estimation, unforeseen site conditions, poor investigation, client-initiated variations and political pressure during the construction.

Similarly, Dickson et al. [13] identified the top reasons behind the factors that caused $\mathrm{COs}$ in construction projects in Kenya. The top five causes were payment delays for land acquisition, changes in site conditions, client scope, client schedule and a lack of coordination between contracting parties. The modern construction industry in the United States generated $5 \%$ of the country's gross domestic product (GDP) in 2016 [14]. The five frequent road maintenance activities were selected to identify the causes and preventive measures of the COs. The road maintenance activities 
included chip seals, striping, asphalt overlay, slope repairs and debris removal [15].

Waty and Sulistio [16] stated that they identified 732 changes in the road construction items in 16 projects. Additionally, risk identification resulted in 31 construction work items. The highest percentage was Thermoplastic Road Marking work, followed by 30 other construction work items. The average percentage of jobs that experienced the biggest change order in the road construction projects in Banten was $19.64 \%$ in the U-shaped channel work for DS 1 type, [17]. Almost all Indonesia's construction projects have experienced contract changes, also called a contract Change Order or Addendum. A contract addendum greatly affects changes in prices, costs and time in construction, [18]. Change Order or Addendum contracts are formal documents signed by owners and contractors to compensate contractors for losses due to changes, additional work, delays, or other activities. Addendum contracts are approved by the owner and contractor as stated in terms of the contract document [19]. The average percentage for the less work of road projects in Jakarta is $54.9231 \%$ for the road of medium quality concrete (strength 20 Mpa), [20]. The main causes of change orders for the road construction projects in West Java Province are the contract omissions, increases caused by owners and high costs of contract items [21].

Research Objectives: To determine the factors causing the change order from the owner's point of view using the Relative Importance Index quantification and demonstrating the ranking of factors and groups according to interests with respect to change orders.

\section{Literature review}

The causes of the Change Order for road construction projects in Banten are [17]:

- Unrealistic design period,

- Low cost of consultants or less experienced designers,

- Unavailability of overall project planning,

- The owner instructing the design modifications and

- Owner instructing additional work.

The main factor causing the biggest Change Order for each question category [17] from the contractor's side is the mismatch between the design drawing and the field conditions. Another cause is the change in the plan drawing and the addition of work.

There are 50 factors causing change orders [5], categorized under construction and administrative needs and parties involved. These categories are further divided into twelve groups.

\section{A Construction Needs}

\section{A.1. Planning and Design}

1. Mistakes in planning,

2. Estimation errors and omissions. ,3. Incomplete contract,

4. Mismatch between images and field conditions,
5. Incomplete specifications,

6. Changes in planning,

7. Additional scope,

8. Reduction of the scope,

9. Temporary work termination,

10. Contradictory or less-strict contract terms,

11. Tight schedule,

12. Delays in equipment approval for design drawings or owner's fixtures,

13. Schedule repair orders and

14. Schedule Acceleration Command.

\section{A.2. Underground Conditions}

1. Incomplete field investigations,

2. Improvement of underground investigations,

3. Different underground conditions and

4. Underground seepage due to excavation.

\section{A.3. Work Safety Considerations}

1. Work safety considerations,

2. Considerations of Field Security and

3. Additional security facilities.

\section{A.4 Natural Factors}

1. Landslides,

2. Floods,

3. Land subsidence and

4. Unusual weather.

B. Administrative Needs

B.1. Employment Change Regulations (CWR)

1. Revised DGH planning regulations and

2. Improved environmental protection regulations.

B.2. Changes from the Competent Authority (CDA)

1. Political considerations,

2. Initial placement of newly constructed facilities,

3. Market changes and

4. Domination of superior authority.

B.3 Commissioning and Handover (Purchase Hand Over)

1. Additional functionality and maintenance requirements,

2. The need for project-related use and

3. Additional needs for future safety considerations.

B.4 Situation of the Surrounding Environment

1. Additional facilities for the neighborhood,

2. Reducing or stopping the construction partly due to environmental problems and

3. Special requests of the City Council.

B.5 Changes to Other Changes

1. Coordination with utility systems,

2. Requirements of the DGH planning agency and

3. Contract conflicts and disputes.

C. Parties Involved

C.1. The Owner

1. Lack of control,

2. The owner's incapacity and

3 . Tardiness of the owner.

C.2. Contractor

1. Lack of teamwork,

2. Inadequate equipment or labor,

3. Failure of contractors or subcontractors, 
4. Labor disputes and

5. Contractor delays.

\section{C.3. Other Parties}

1. The incapacity of the third party and

2. Third-party interference.

\subsection{Research object}

The research on change orders was conducted in Banten Province, the Special Capital Region of Jakarta and West Java Province on road construction projects.

\section{$3 \quad$ Methodology}

Interviews and questionnaires were distributed to the Department of Public Works and Public Housing of DKI Jakarta Province, Banten Province and West Java Province as the owner.

\subsection{Change order data analysis}

The results of the questionnaire about the factors causing the change order of the owners were processed using validity and reliability tests.

After passing validity and reliability, the results are analyzed from the Relative Importance Index and summarized to rank the causes of change for road construction projects

\subsection{Data collection}

Data were collected by observing the road project records in DKI Jakarta, Banten and West Java
Provinces regarding the contract addendum or change order. In addition, data collection involved distributing questionnaires to the project owners.

The questionnaire values were measured using the Likert scale, which uses several question items to measure individual behavior. The measurement involves responding to five choice points on each question item. The scale of the factors causing change orders on a construction project ranged between "does not happen" and "often occurs".

\subsection{Data processing}

The data collected were processed and tabulated in excel. The accuracy of the data was measured using the reliability and validity tests. Additionally, the Relative Importance Index (RII) method as a Ranking technique was applied to each statement before comparing the responses from the owners.

\subsection{Validity test}

A validity test was conducted using the Pearson correlation formula with the IBM SPSS program by comparing the calculated r-value (corrected item-total correlation) with the $r$ value in Table 1 . The data is valid when the r-count $\geq \mathrm{r}$ table. The formula used to find the Pearson correlation coefficient is:

$r_{x y}=\frac{n \sum x y-\left(\sum x\right)\left(\sum y\right)}{\sqrt{\left(\sum x^{2}-\left(\sum x\right)^{2}\right)\left(n \sum y^{2}-\left(\sum y\right)^{2}\right)}}$,

where:

$\mathrm{x}=$ score obtained by the subject from all the items,

$\mathrm{y}=$ total score from all the items,

$\mathrm{x}=$ number of scores in the distribution $\mathrm{x}$,

$\mathrm{y}=$ total score in the $\mathrm{y}$ distribution,

Table 1 Distribution table value $r$ table significance $5 \%$ and $11 \%$

\begin{tabular}{|c|c|c|c|c|c|}
\hline \multirow{2}{*}{$\mathrm{N}$} & \multicolumn{2}{|c|}{ The Level of Significance } & \multirow{2}{*}{$\mathrm{N}$} & \multicolumn{2}{|c|}{ The Level of Significance } \\
\hline & $5 \%$ & $1 \%$ & & $5 \%$ & $1 \%$ \\
\hline 3 & 0.997 & 0.999 & 38 & 0.320 & 0.413 \\
\hline 4 & 0.950 & 0.990 & 39 & 0.316 & 0.408 \\
\hline 5 & 0.878 & 0.959 & 40 & 0.312 & 0.403 \\
\hline 6 & 0.811 & 0.917 & 41 & 0.308 & 0.398 \\
\hline 7 & 0.754 & 0.874 & 42 & 0.304 & 0.393 \\
\hline 8 & 0.707 & 0.834 & 43 & 0.301 & 0.389 \\
\hline 9 & 0.666 & 0.798 & 44 & 0.297 & 0.384 \\
\hline 10 & 0.632 & 0.765 & 45 & 0.294 & 0.380 \\
\hline 11 & 0.602 & 0.735 & 46 & 0.291 & 0.376 \\
\hline 12 & 0.576 & 0.708 & 47 & 0.288 & 0.372 \\
\hline 13 & 0.553 & 0.684 & 48 & 0.284 & 0.368 \\
\hline 14 & 0.532 & 0.661 & 49 & 0.281 & 0.364 \\
\hline 15 & 0.514 & 0.641 & 50 & 0.279 & 0.361 \\
\hline 16 & 0.497 & 0.623 & 55 & 0.266 & 0.345 \\
\hline 17 & 0.482 & 0.606 & 60 & 0.254 & 0.330 \\
\hline 18 & 0.468 & 0.590 & 65 & 0.244 & 0.317 \\
\hline
\end{tabular}


$\mathrm{x}^{2}=$ sum of squares in the distribution score $\mathrm{x}$, $\mathrm{y}^{2}=$ sum of squares in the $\mathrm{y}$ distribution score and $\mathrm{n}=$ number of respondents.

\subsection{Reliability test}

A reliability test was performed to prove the questionnaire's trustworthiness by calculating the alpha coefficient. The questions are reliable when the Cronbach's Alpha coefficient is above 0.7. Reliability testing was conducted using the IBM SPSS program.

The formula to find the value of Cronbach's alpha is as follows:

$$
r_{11}=\left(\frac{n}{n-1}\right)\left(1-\frac{\sum \sigma_{t}^{2}}{\sigma_{t}^{2}}\right)
$$

where:

$r_{11}=$ reliability coefficient (Cronbach's alpha value),

$n=$ number of statement details,

$\sum \sigma_{i}^{2}=$ the variance in the score of the i-th question and

$\sigma_{t}^{2}=$ total score variance.

One reliability variable shows the extent to which the different latent factors [22] are accepted satisfactorily when the Cronbach's Alpha coefficient reported is greater than the 0.7 recommended by [23] and [24].

\subsection{Quantification of causes change order factors using the RII method}

RII compares the owners' responses on road construction projects.

$$
R I I(\%)=\frac{5 n 5+4 n 4+3 n 3+2 n 2+1 n 1}{W *(n 5+n 4+n 3+n 2+n 1)} \times 100 \%,
$$

where:

$n 5$ : The number of respondents that chose a scale of 5 , $n 4$ : The number of respondents that chose a scale of 4 , $n 3$ : The number of respondents that chose a scale of 3 , $n 2$ : The number of respondents that chose a scale of 2 and

$n 1$ : The number of respondents that chose a scale of 1 , $W$ : The largest scale on the Likert scale.

The aim of this part is to quantify the relative importance of causes change order factors. The results of this part demonstrated the ranking of the factors and group according to their level of importance in relation to causes of change order.

The research methodology for quantification of the relative importance of the causes change order factors by the RII method can be summarized as follows:

First: Initially there were 50 causes of change orders, which were divided into 12 groups obtained from the previous literature, [25-28]).
Second: An interview questionnaire that unifies the owner's perception of the relationship of interest about the cause of the change order. Then the questionnaire was filled out by 32 experience construction professionals from owners. The collected data were analyzed through the relative importance indices. The analysis revealed the factors and groups that contributed the most to causes of change order. The participants' groups consisted of professionals with various years of experience: from 0-10 years (31\%), 11-20 years (56\%) and 21-30 years (13\%), what can be seen on Table 2 .

\subsection{Interview on causes of change order}

The interviewees were asked to fill out a questionnaire form about causes of change order and groups and complete the questionnaire form by assigning values of importance to the factors ranging from 1 (very low level of importance) to 5 (very high level of importance). Interviewees have significant information about the factors causing change orders in construction projects and are an expert in the construction projects. The interviewees checked and evaluate 50 well-organized causal factors based on their professional judgment as owners and groups of factors causing change orders of road construction projects.

\section{Discussion}

\subsection{Respondent data}

This study was conducted on 32 respondents based on their years of experience in road construction projects.

1. Respondent Data Based on Years' Experience

From 32 respondents, $31 \%$ had $0-10$ years of experience, $56 \%$ had $11-20$ of experience, while $13 \%$ had 21-30 years of experience, as shown in Figure 1.

\subsection{Validity test}

The validity test, using the bivariate correlation, showed that the indicator of Added the Scope of the Planning and Design (XA) causal factor was invalid. Therefore, 49 causal factors were valid indicators. The invalidity was caused by an $\mathrm{R}$ count of 0.309 , smaller than the $\mathrm{R}$ table value of 0.361 , as seen in Table 3 .

The validity test results showed 48 variable factors that cause the change order. They could be used in the test phase with the corrected item selected method to produce 48 causal factors, as shown in Table 4 . The cause factor that is not valid is the change in the Planning Drawings from the Planning and Design group because $R$ count $>R$ table that is $0.313<0.361$. 


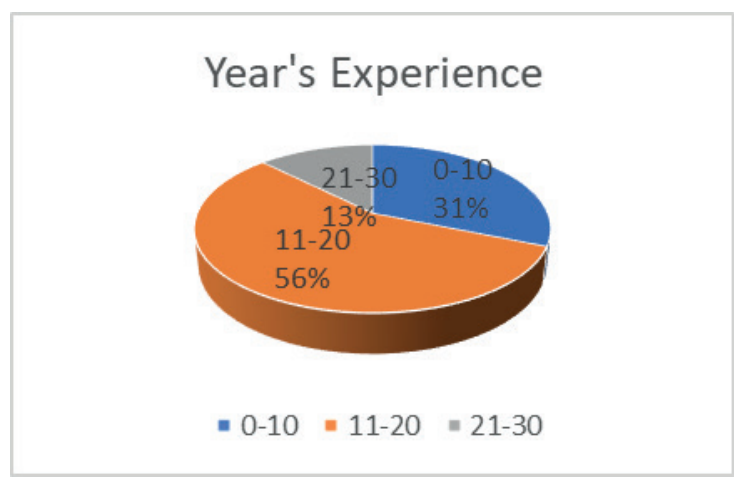

Figure 1 Pie chart of respondents' characteristics based on years of experience

Table 2 List of interview respondents according to their years of experience in construction projects

\begin{tabular}{|c|c|c|c|c|}
\hline Number & Title & Experience & Sector & Party \\
\hline 1 & Engineer & $0-10$ & Public & Owner \\
\hline 2 & Site Engineer & $11-20$ & Public & Owner \\
\hline 3 & Engineer & $0-10$ & Public & Owner \\
\hline 4 & Site Engineer & $11-20$ & Public & Owner \\
\hline 5 & Engineer & $0-10$ & Public & Owner \\
\hline 6 & Engineer & $0-10$ & Public & Owner \\
\hline 7 & Engineer & $0-10$ & Public & Owner \\
\hline 8 & Engineer & $0-10$ & Public & Owner \\
\hline 9 & Site Engineer & $11-20$ & Public & Owner \\
\hline 10 & Site Engineer & $11-20$ & Public & Owner \\
\hline 11 & Site Engineer & $11-20$ & Public & Owner \\
\hline 12 & Site Engineer & $11-20$ & Public & Owner \\
\hline 13 & Site Engineer & $11-20$ & Public & Owner \\
\hline 14 & Site Engineer & $11-20$ & Public & Owner \\
\hline 15 & Site Engineer & $11-20$ & Public & Owner \\
\hline 16 & Engineer & $0-10$ & Public & Owner \\
\hline 17 & Site Engineer & $11-20$ & Public & Owner \\
\hline 18 & Site Engineer & $11-20$ & Public & Owner \\
\hline 19 & Engineer & $0-10$ & Public & Owner \\
\hline 20 & Site Engineer & $11-20$ & Public & Owner \\
\hline 21 & Site Engineer & $11-20$ & Public & Owner \\
\hline 22 & Site Engineer & $11-20$ & Public & Owner \\
\hline 23 & Site Engineer & $11-20$ & Public & Owner \\
\hline 24 & Project Leader & $21-30$ & Public & Owner \\
\hline 25 & Site Engineer & $11-20$ & Public & Owner \\
\hline 26 & Project Leader & $21-30$ & Public & Owner \\
\hline 27 & Engineer & $0-10$ & Public & Owner \\
\hline 28 & Site Engineer & $11-20$ & Public & Owner \\
\hline 29 & Site Engineer & $11-20$ & Public & Owner \\
\hline 30 & Project Leader & $21-30$ & Public & Owner \\
\hline 31 & Project Leader & $21-30$ & Public & Owner \\
\hline 32 & Engineer & $0-10$ & Public & Owner \\
\hline
\end{tabular}


Table 3 Validity test results based on bivariate correlation output

\begin{tabular}{|c|c|c|c|c|}
\hline Num. & Factors of Causing Change Order & $\mathrm{R}$ table & $\mathrm{R}$ calculate & Result \\
\hline$\bullet$ & Construction Needs & & & \\
\hline A. & Planning and Design & & & \\
\hline 1 & Errors in construction planning & 0.361 & 0.711 & Valid \\
\hline 2 & Errors and omissions in determining the volume & 0.361 & 0.642 & Valid \\
\hline 3 & Incomplete contract & 0.361 & 0.605 & Valid \\
\hline 4 & A mismatch between design drawings and field conditions & 0.361 & 0.457 & Valid \\
\hline 5 & Incomplete engineering design specifications or criteria & 0.361 & 0.413 & Valid \\
\hline 6 & The change in the Planning Drawing & 0.361 & 0.448 & valid \\
\hline 7 & Reduction of work & 0.361 & 0.580 & Valid \\
\hline 8 & Temporary work stoppage & 0.361 & 0.448 & Valid \\
\hline 9 & Contradictory contracts & 0.361 & 0.718 & Valid \\
\hline 10 & Overlapping scheduling & 0.361 & 0.628 & Valid \\
\hline 11 & Delays in design or equipment approval from the owner & 0.361 & 0.790 & Valid \\
\hline 12 & Schedule repair orders & 0.361 & 0.460 & Valid \\
\hline 13 & Schedule acceleration command & 0.361 & 0.399 & Valid \\
\hline 14 & Added scope & 0.361 & 0.309 & Not valid \\
\hline
\end{tabular}

Table 4 Validity test results with corrected item statistic

\begin{tabular}{cllcl}
\hline Num. & Factors of Causing Change Order & R table & R calculated & Result \\
\hline$\bullet$ & CONSTRUCTION NEEDS & & & \\
A. & PLANNING AND DESIGN & & & \\
1 & Errors in construction planning & 0.361 & 0.711 & Valid \\
2 & Errors and omissions in determining the volume & 0.361 & 0.642 & Valid \\
3 & Incomplete contract & 0.361 & 0.605 & Valid \\
4 & A mismatch between design drawings and field conditions & 0.361 & 0.457 & Valid \\
5 & Incomplete engineering design specifications or criteria & 0.361 & 0.413 & Valid \\
6 & The change in the Planning Drawing & 0.361 & 0.313 & Not Valid \\
7 & Reduction of work & 0.361 & 0.580 & Valid \\
8 & Temporary work stoppage & 0.361 & 0.448 & Valid \\
9 & Contradictory contracts & 0.361 & 0.718 & Valid \\
10 & Overlapping scheduling & 0.361 & & Valid \\
11 & Delays in design or equipment approval from the owner & 0.361 & 0.628 & Valid \\
12 & Schedule repair orders & 0.361 & 0.790 & Valid \\
13 & Schedule acceleration command & 0.361 & 0.460 & Valid \\
\hline
\end{tabular}

\subsection{Reliability test}

The reliability test is conducted to measure how reliable the questionnaire is. The test was conducted using the internal reliability coefficient of alpha to determine the relationships between the questions in the questionnaire. The reliability test involved calculating the alpha coefficient, where the questions are said to be reliable when the Cronbach Alpha coefficient value is above 0.7 [23] and [24]. Reliability test results, using the IBM SPSS program given in Table 4, show that 12 of the 48 factors cause change order, with $\mathrm{R}$ greater than 0.7
The IBM SPSS program test showed that the entire group comprising 48 factors caused change orders in the road construction projects.

\subsection{Calculation of RII}

The Relative Importance Index RII is used as a ranking technique for each statement filled by respondents from the order of 1 (very low importance) to 5 (very high importance) RII values range from 0 to 1 ( 0 being non-inclusive); and the higher the RII, the more important the cause of the change order.

The results are shown in Table 6 regarding 
Table 5 Reliability test results of factors causing the change order

\begin{tabular}{clc}
\hline Num. & Group Factors causing the change order (X) & R calculated \\
\hline 1 & Planning and Design (XA) & 0.879 \\
2 & Underground Condition (XB) & 0.799 \\
3 & Safety Consideration (XC) & 0.811 \\
4 & Natural Factors (XD) & 0.867 \\
5 & Change To the Rules of Work (YA) & 0.807 \\
6 & Change from the Authorities (YB) & 0.819 \\
7 & Commissioning (YC) & 0.909 \\
8 & Application from Surrounding Environment (YD) & 0.859 \\
9 & Other Changes (YE) & 0.849 \\
10 & The Owner (ZA) & 0.919 \\
11 & Contractor (ZB) & 0.884 \\
12 & Other Parties (ZC) & 0.941 \\
\hline
\end{tabular}

Table 6 Overall RII calculation results (ranking of causes of change orders) from group planning and design to underground conditions

\begin{tabular}{|c|c|c|c|c|c|c|c|c|}
\hline \multirow[b]{2}{*}{ Num. } & \multirow[b]{2}{*}{ Factors of causing the change order } & \multicolumn{7}{|c|}{ Respondent Scores } \\
\hline & & $\begin{array}{c}1 \\
\text { very low } \\
\text { importance }\end{array}$ & $\begin{array}{c}2 \\
\text { Low } \\
\text { importance }\end{array}$ & $\begin{array}{c}3 \\
\text { Medium } \\
\text { importance }\end{array}$ & $\begin{array}{c}4 \\
\text { High } \\
\text { importance }\end{array}$ & $\begin{array}{c}5 \\
\text { Very high } \\
\text { importance }\end{array}$ & RII & Rank \\
\hline I & Construction Needs & & & & & & & \\
\hline A. & Planning and Design & 1 & 2 & 3 & 4 & 5 & & \\
\hline 1 & Errors in construction planning & 2 & 11 & 10 & 8 & 1 & 0.57 & 6 \\
\hline 2 & $\begin{array}{l}\text { Errors and omissions in determining } \\
\text { the volume }\end{array}$ & 1 & 12 & 13 & 5 & 1 & 0.56 & 7 \\
\hline 3 & $\begin{array}{l}\text { A mismatch between design drawings } \\
\text { and field conditions }\end{array}$ & 0 & 6 & 13 & 13 & 0 & 0.64 & 1 \\
\hline 4 & $\begin{array}{l}\text { Incomplete engineering design } \\
\text { specifications or criteria }\end{array}$ & 3 & 8 & 14 & 7 & 0 & 0.56 & 7 \\
\hline 5 & Reduction of work & 0 & 11 & 13 & 5 & 3 & 0.51 & 11 \\
\hline 6 & Temporary work stoppage & 6 & 11 & 8 & 6 & 1 & 0.50 & 12 \\
\hline 7 & Contradictory contracts & 3 & 18 & 8 & 2 & 1 & 0.53 & 10 \\
\hline 8 & Overlapping scheduling & 12 & 16 & 2 & 1 & 1 & 0.47 & 16 \\
\hline 9 & $\begin{array}{l}\text { Delay in design/ equipment approval } \\
\text { from the owner }\end{array}$ & 6 & 13 & 11 & 0 & 2 & 0.49 & 13 \\
\hline 10 & Schedule repair orders & 5 & 13 & 9 & 4 & 1 & 0.56 & 7 \\
\hline 11 & Schedule acceleration command & 1 & 10 & 16 & 5 & 0 & 0.59 & 4 \\
\hline 12 & Incomplete contract & 0 & 11 & 11 & 10 & 0 & 0.59 & 4 \\
\hline B. & Under Ground Conditions & 1 & 2 & 3 & 4 & 5 & & \\
\hline 13 & $\begin{array}{l}\text { Incomplete field ground investigations } \\
\text { or tests }\end{array}$ & 2 & 16 & 8 & 4 & 2 & 0.53 & 10 \\
\hline 14 & $\begin{array}{l}\text { Underground upgrades and } \\
\text { investigations }\end{array}$ & 1 & 14 & 10 & 6 & 1 & 0.55 & 9 \\
\hline 15 & $\begin{array}{l}\text { Different underground conditions on } \\
\text { the investigation results }\end{array}$ & 4 & 12 & 10 & 6 & 0 & 0.51 & 12 \\
\hline 16 & Underground seepage from excavation & 3 & 11 & 12 & 6 & 0 & 0.53 & 10 \\
\hline C. & Safety Consideration & 1 & 2 & 3 & 4 & 5 & & \\
\hline 17 & Work safety consideration & 3 & 11 & 11 & 7 & 0 & 0.54 & 9 \\
\hline 18 & Considerations of Field Security & 0 & 10 & 13 & 8 & 1 & 0.60 & 3 \\
\hline 19 & Additional security facilities & 1 & 12 & 13 & 6 & 0 & 0.55 & 7 \\
\hline
\end{tabular}




\begin{tabular}{|c|c|c|c|c|c|c|c|c|}
\hline D. & Natural Factors & 1 & 2 & 3 & 4 & 5 & & \\
\hline 20 & Floods & 3 & 12 & 11 & 4 & 2 & 0.54 & 9 \\
\hline 21 & Landslide & 2 & 16 & 7 & 5 & 2 & 0.53 & 10 \\
\hline 22 & Land subsidence & 2 & 13 & 9 & 7 & 1 & 0.53 & 10 \\
\hline 23 & Unusual weather & 4 & 11 & 10 & 7 & 0 & 0.53 & 10 \\
\hline II & Administrative Needs & & & & & & & \\
\hline A. & Changes to the rule of work & 1 & 2 & 3 & 4 & 5 & & \\
\hline 1 & Changes from city planning regulation & 4 & 19 & 9 & 0 & 0 & 0.43 & 17 \\
\hline 2 & $\begin{array}{l}\text { Change based on environmental } \\
\text { protection }\end{array}$ & 2 & 19 & 9 & 2 & 0 & 0.47 & 15 \\
\hline B. & Changes for the Authorities & 1 & 2 & 3 & 4 & 5 & & \\
\hline 3 & $\begin{array}{l}\text { Differences in views between } \\
\text { government officials }\end{array}$ & 3 & 19 & 8 & 1 & 1 & 0.46 & 16 \\
\hline 4 & $\begin{array}{l}\text { Change in the initial placement of } \\
\text { facilities and infrastructure }\end{array}$ & 2 & 19 & 9 & 2 & 0 & 0.47 & 15 \\
\hline 5 & Market changes & 3 & 18 & 7 & 4 & 0 & 0.48 & 14 \\
\hline 6 & $\begin{array}{l}\text { Domination of superior or leader } \\
\text { authority }\end{array}$ & 5 & 16 & 9 & 1 & 1 & 0.46 & 16 \\
\hline C. & COMMISSIONING & 1 & 2 & 3 & 4 & 5 & & \\
\hline 7 & $\begin{array}{l}\text { Additional needs for care or } \\
\text { maintenance }\end{array}$ & 1 & 20 & 5 & 6 & 0 & 0.50 & 12 \\
\hline 8 & Additional need for related projects & 7 & 11 & 12 & 1 & 1 & 0.53 & 10 \\
\hline 9 & $\begin{array}{l}\text { Additional needs for future safety } \\
\text { considerations }\end{array}$ & 4 & 15 & 8 & 4 & 1 & 0.54 & 9 \\
\hline D. & $\begin{array}{l}\text { Application for Surrounding } \\
\text { Environment }\end{array}$ & 1 & 2 & 3 & 4 & 5 & & \\
\hline 10 & Additional facilities for residents & 6 & 8 & 11 & 6 & 1 & 0.53 & 10 \\
\hline 11 & $\begin{array}{l}\text { Reduced or delayed construction partly } \\
\text { due to problems }\end{array}$ & 7 & 11 & 12 & 1 & 1 & 0.46 & 16 \\
\hline 12 & $\begin{array}{l}\text { Request from officials or local } \\
\text { government (CSR) }\end{array}$ & 4 & 15 & 8 & 4 & 1 & 0.49 & 13 \\
\hline E. & Other Changes & 1 & 2 & 3 & 4 & 5 & & \\
\hline 13 & Late coordination delivery & 4 & 15 & 7 & 5 & 1 & 0.50 & 12 \\
\hline 14 & Needs from other institution & 4 & 17 & 7 & 3 & 1 & 0.48 & 14 \\
\hline 15 & Conflict contract and disputes & 7 & 18 & 4 & 2 & 1 & 0.53 & 10 \\
\hline III & Parties Involves & 1 & 2 & 3 & 4 & 5 & & \\
\hline A. & THE OWNER & & & & & & & \\
\hline 1 & Lack of control & 3 & 16 & 8 & 5 & 0 & 0.49 & 13 \\
\hline 2 & Owner's incompetence & 5 & 16 & 8 & 3 & 0 & 0.46 & 16 \\
\hline 3 & Late owner & 5 & 16 & 8 & 3 & 0 & 0.46 & 16 \\
\hline B. & CONTRACTOR & 1 & 2 & 3 & 4 & 5 & & \\
\hline 4 & Lack of teamWork & 0 & 12 & 10 & 10 & 0 & 0.59 & 4 \\
\hline 5 & Inadequate Tools & 0 & 13 & 9 & 10 & 0 & 0.58 & 5 \\
\hline 6 & Failure of the contractor's ability & 2 & 12 & 11 & 7 & 0 & 0.54 & 9 \\
\hline 7 & Labor Disputes & 4 & 12 & 8 & 8 & 0 & 0.53 & 10 \\
\hline 8 & Contractor Delay & 0 & 11 & 7 & 14 & 0 & 0.62 & 2 \\
\hline C. & OTHER PARTIES & 1 & 2 & 3 & 4 & 5 & & \\
\hline 9 & The incapacity of Third Party & 2 & 11 & 13 & 5 & 1 & 0.55 & 8 \\
\hline 10 & Third-Party interference & 2 & 12 & 12 & 5 & 1 & 0.54 & 9 \\
\hline
\end{tabular}


Table7 Mean RII and ranking of groups of the change order causes

\begin{tabular}{lcc}
\hline Group & RII & Rank \\
\hline Contractor & 0.572 & 1 \\
Safety Consideration & 0.563 & 2 \\
Planning and Design & 0.547 & 3 \\
Other Parties & 0.545 & 4 \\
Natural Factors & 0.533 & 5 \\
Under Ground & 0.530 & 6 \\
Conditions & & 7 \\
Commissioning & 0.523 & 8 \\
Other Changes & 0.503 & 9 \\
Application for Surrounding Environment & 0.493 & 10 \\
The Owner & 0.47 & 11 \\
Changes for the Authorities & 0.467 & 12 \\
Changes to the rule of work & 0.45 & \\
\hline
\end{tabular}

Table 8 The most important factors of causing the change order

\begin{tabular}{cllcc}
\hline Num. & Factors Causing of Change Order & Group & RII & Rank \\
\hline 1 & A mismatch between design drawings and field conditions & Planning and Design & 0.64 & 1 \\
2 & Contractor Delay & Contractor & 0.62 & 2 \\
3 & Considerations of Field Security & Safety Consideration & 0.6 & 3 \\
4 & Lack of Work & Contractor & 0.59 & 4 \\
5 & Schedule acceleration command & Planning and Design & 0.59 & 4 \\
6 & Incomplete contract & Planning and Design & 0.59 & 4 \\
7 & Inadequate Tools & Contractor & 0.58 & 5 \\
8 & Errors in construction planning & Planning and Design & 0.57 & 6 \\
9 & Errors and omissions in determining the volume & Planning and Design & 0.56 & 7 \\
10 & Incomplete engineering design specifications or criteria & Planning and Design & 0.56 & 7 \\
11 & Schedule repair orders & Planning and Design & 0.56 & 7 \\
\hline
\end{tabular}

Table 9 The least important factors causing the change orders

\begin{tabular}{|c|c|c|c|c|}
\hline Num. & Factors Causing of Change Order & Group & RII & Rank \\
\hline 1 & Change for city planning regulation & Change the rule of work & 0.43 & 17 \\
\hline 2 & Differences in views between government officials & Changes for the Authorities & 0.46 & 16 \\
\hline 3 & Domination of superior or leader authority & Changes for the Authorities & 0.46 & 16 \\
\hline 4 & Reduced or delayed construction partly due to problems & Application for Surrounding Environment & 0.46 & 16 \\
\hline 5 & Owner's incompetence & The Owner & 0.46 & 16 \\
\hline 6 & Late owner & The Owner & 0.46 & 16 \\
\hline 7 & $\begin{array}{l}\text { Change in the initial placement of facilities and } \\
\text { infrastructure }\end{array}$ & Changes for the Authorities & 0.47 & 15 \\
\hline 8 & Overlapping scheduling & Planning and Design & 0.47 & 15 \\
\hline 9 & Change based on environmental protection & Change the rule of work & 0.47 & 15 \\
\hline 10 & Market changes & Change the rule of work & 0.48 & 15 \\
\hline 11 & Needs from other institution Schedule repair orders & Other Changes & 0.48 & 15 \\
\hline
\end{tabular}

the calculation of the overall causative average RII, the RII was then assessed. The results are shown in Table 6, which calculates the overall mean of RII causes

\subsection{RII based on overall groups}

Table 6 shows the calculation of the Relative Importance Index from the 48 causes of change 
orders that passed the validity and reliability test.

\section{Result}

Based on the rankings in Tables 6 , the average RII and the rankings of all the groups are shown in Table 7 , the 11 most important factors causing a change in order are shown in Table 8 and the 15 least important factors causing an order change are shown in Table 9. According to group rankings, the three factors from each group that contributed the most to change the order are presented in the following terms.

From the results of the overall RII calculation, it is found that the three highest causes of change orders are:

1. A mismatch between design drawings and field conditions,

2. Contractor delay and

3. Considerations of Field Security.

Contractors $(\mathrm{RII}=\mathbf{0 . 5 7 2})$

The most important group to cause change order was contractors whose significant factors were contractor delays $(\mathrm{RII}=0.62)$, lack of team work $(\mathrm{RII}=0.59)$ and inadequate tools $(\mathrm{RII}=0.58)$.

Safety Consideration $(\mathrm{RII}=\mathbf{0 . 5 6 3})$

The second most important group was Safety Consideration whose significant factors were consideration of the field security $(\mathrm{RII}=0.6)$, additional security facilities (RII $=0.55)$ and Work safety consideration $(\mathrm{RII}=0.54)$.

\section{Planning and design $(\mathrm{RII}=\mathbf{0 . 5 4 7})$}

The third most important group was Planning and Design. The significant factors were A mismatch between design drawings and field conditions (RII = $0.64)$ and Schedule acceleration command $(\mathrm{RII}=0.59)$ and an Incomplete contract (RII = 0.59).

Other parties $(\mathrm{RII}=\mathbf{0 . 5 4 5})$

After Planning and Design, other parties group of causes of the change order factors was ranked as the fourth most important group. The significant factors were The incapacity of the Third Party $(\mathrm{RII}=0.55)$ and Third-Party interference (RII = 0.54).

\section{Natural factors $($ RII $=\mathbf{0 . 5 4 5})$}

After Others Parties, natural factors group was ranked as the fifth most important group. The significant factors were flood $(\mathrm{RII}=0.54)$, Landslide $(\mathrm{RII}=0.53)$, Land subsidence $(\mathrm{RII}=0.53)$ and Unusual weather $(\mathrm{RII}=0.53)$.

\section{Underground conditions $(\mathrm{RII}=\mathbf{0 . 5 3})$}

After Natural Factors, underground conditions group was ranked as the sixth most important group. The significant factors were Underground upgrades and investigations $(\mathrm{RII}=0.55)$ and Incomplete field ground investigations or tests $(\mathrm{RII}=0.53)$ and Underground seepage from excavation $(\mathrm{RII}=0.53)$.

Commissioning $(\mathrm{RII}=\mathbf{0 . 5 2 3})$

After Underground conditions, commissioning was ranked as the seventh most important group. The significant factors were Additional needs for future safety considerations $(\mathrm{RII}=0.54)$, Additional need for related projects $(\mathrm{RII}=0.53)$ and Additional needs for care or maintenance $(\mathrm{RII}=0.50)$.

\section{Other changes $(\mathrm{RII}=\mathbf{0 . 5 0 3})$}

After commissioning, other changes group was ranked as the eighth most important group. The significant factors were Conflict contract and disputes $(\mathrm{RII}=0.53)$, Late coordination delivery $(\mathrm{RII}=0.50)$ and Needs from other institution (RII $=0.48$ ).

Application for surrounding environment (RII = 0.493)

After other changes, Application for Surrounding Environment was ranked as the ninth most important group. The significant factors were Additional facilities for residents (RII $=0.53$ ), Request from officials or local government $(\mathrm{CSR})(\mathrm{RII}=0.49)$ and Reduced or delayed construction partly due to problems $(\mathrm{RII}=0.46)$.

The Owner $(\mathrm{RII}=\mathbf{0 . 4 7})$

After Application for Surrounding Environment, The Owner was ranked as the tenth most important group. The significant factors were Lack of control (RII = $0.49)$, Owner's incompetence $(\mathrm{RII}=0.46)$ and Late owner $(\mathrm{RII}=0.46)$.

Changes for the Authorities ( RII = 0.467)

After The Owner, Changes for the Authorities was ranked as the eleventh most important group. The significant factors were Market changes $($ RII $=0.48)$, Change in the initial placement of facilities and infrastructure $(\mathrm{RII}=0.47)$, Differences in views between government officials $(\mathrm{RII}=0.46)$ and Domination of superior or leader authority $(\mathrm{RII}=0.46)$.

\section{Changes to the rule of work $(\mathrm{RII}=\mathbf{0 . 4 5})$}

After Changes for the Authorities, Changes to the rule of work was the last and least important group. The significant factors were Change based on environmental protection $(\mathrm{RII}=0.47)$ and Changes from city planning regulation $(\mathrm{RII}=0.43)$.

\section{Summary}

Causes of change orders can be avoided when the causes are clearly identified. The purpose of this paper was to determine the ranking of the causes of change orders. Through interviews and questionnaires, 50 causes were obtained, which were included in 12 categories of causes of change orders. The 12 categories from the highest to lowest are contractor, safety consideration, planning and design, other parties, natural factors, underground conditions, commissioning, other changes, application for surrounding environment, the owner, change for authorities and change to the rule of work. Apart from this, of the 50 causes of change orders, there are three causes of the highest change orders, namely: A mismatch between the design drawings 
and field conditions, contractor delay and field safety considerations.

This paper quantifies the relative importance of change order causative factors and shows the ranking of change order causative factors and groups according to their level of importance for change order causes. This goal is achieved through analysis of results of the interviews. According to RII calculations, all the factors and groups are ranked. The paper discussed the most significant factors and groups of causes regarding the causes of change orders. The most important and least important factors and groups are achieved through ranking results.

\subsection{Analysis of the overall results}

Analysis of the causes of change orders for the road construction projects consists of the three highest causes overall, namely:

1. A mismatch between design drawings and field conditions.

This is because the consultant did not get enough time [17] resulting in design drawings and field conditions that were not appropriate, especially when implementation had a long time-lapse from planning so that the field conditions had changed. There are also many consultants who have low competence who have not been able to handle the project problems, resulting in a mismatch between the design drawings and field conditions.

2. Contractor's Delay

Contractor's delays are caused because contractors have to incur additional costs so they spend a lot of working capital [17], which causes contractor delays when completing the road construction project work.

3. Consideration of the Field Security

Consideration of the field security is something that needs to be considered because security in the field is an important factor because, in the project field, which is especially far from crowds or from people's homes, it is very easy for theft and loss of a lot of goods if not guarded and considered carefully.

\subsection{Analysis per group}

\section{Contractor}

1. The contractor must pay attention to the contractor's delay factor because the contractor has to incur additional costs so that he spends a lot of working capital, which causes the contractor's delay in completing the road construction project.

2. The contractor must pay attention to the lack of team work because the work team must be able to work well together so that it can complete the road construction projects on time and not experience job changes.
3. The contractor must pay attention to adequate equipment so that the project can run well and does not become the cause of change orders.

\section{Safety considerations}

4. Consideration of the field security is a very decisive factor in causing change orders. The field security is something that needs to be considered because security in the field is an important factor because in the project field, which is usually far from crowds or from people's homes, it is very easy for theft and loss of a lot of goods to occur if not guarded and considered carefully.

5. Additional security facilities are a determining factor to cause change orders because additional facilities are needed to improve security in the field, especially for projects that are far from crowds or in remote places, where more attention has to be paid to security factors in the field.

6. Work safety considerations are a factor in causing change orders because the work safety factors must be considered, since if there were a slight error or mistake in implementation of the work safety, there would definitely be changes in the project costs that encourage change orders.

\section{Planning and design}

7. A mismatch between design drawings and field conditions is the main factor causing change orders. This is because the consultants do not get enough time [17] so that they produce design drawings and field conditions that are not appropriate, especially at the time of implementation if there was a long lapse of time from planning so that field conditions have changed. There are also many consultants who have low competence who have not been able to handle the project problems, resulting in a mismatch between the design drawings and field conditions.

8. Schedule acceleration is the trigger for change orders because of the late schedule that occurs due to design changes resulting in schedule acceleration since it causes an increase in costs, resulting in a change order for the road construction projects.

9. Incomplete contracts are also the cause of change orders because consultants and contractors cannot work properly if there are incomplete contracts so that work can change, which results in change orders

\section{Conclusion}

Based on the above discussion, the following was concluded:

1. The causes of the highest overall change orders by the ranking are:

a. A mismatch between the design drawings and field conditions

b. Contractor's Delay 
c. Consideration of Field Security

2. The causes of the highest change orders based on the group category rankings are:

a. Contractor, consisting of contractor delays, lack of teamwork and inadequate tools

b. Safety Considerations, which consist of Considerations of field security, Additional security facilities and Work safety considerations

c. Planning and Design, which consists of A mismatch between the design drawings and field conditions, Schedule acceleration order, and incomplete contract

\section{Suggestions}

The suggestions proposed to reduce the occurrence of change orders include:
1. Monitoring pictures and field conditions periodically before the implementation.

2. The contractor should pay more attention to the work contract provisions as the executor of the road construction project.

3. More attention should be paid to the field safety factors.

\section{Acknowledgments}

This study was funded by the Ministry of Research and Technology, Indonesia. Therefore, the authors acknowledge the assistance and cooperation of the Ministry of Public Works and Public Housing and Public Works Service DKI Jakarta, Banten and West Java.

\section{References}

[1] FISK, E. R., REYNOLDS, W. D. Construction project administration. 9. ed. Pearson, 2010. ISBN 978-0132866736.

[2] IBBS, W. Quantitative impacts of project change: size issues. Journal of Construction Engineering and Management [online]. 1997, 123(3), p. 308-311. ISSN 0733-9364, eISSN 1943-7862. Available from: https://doi.org/10.1061/(ASCE)0733-9364(1997)123:3(308)

[3] SERAG, E., OLOUFA, A., MALONE, L., RADWAN, E. Model for quantifying the impact of change orders on project cost for US roadwork construction. Journal of Construction Engineering and Management [online]. 2010, 136(9), p. 1015-102. ISSN 0733-9364, eISSN 1943-7862. Available from: https://doi.org/10.1061/ASCECO.19437862.0000206

[4] ANASTOPOLOUS, P. C., LABI, S., BHARGAVA, A., BORDAT, C., MANNERING, F. L. Frequency of change orders in highway construction using alternate count-data modeling methods. Journal of Construction Engineering and Management [online]. 2010, 136(8), p. 886-893. ISSN 0733-9364, eISSN 1943-7862. Available from: https://doi.org/10.1061/ASCECO.1943-7862.0000198

[5] WAMBEKE, B. W., HSIANG, S. M., LIU, M. Causes of variation in construction project task starting times and duration. Journal of Construction Engineering and Management [online]. 2011, 137(9), p. 663-677. ISSN 0733-9364, eISSN 1943-7862. Available from: https://doi.org/10.1061/(ASCE)CO.1943-7862.0000342

[6] WATY, M. Analysis of change orders on road pavement projects / Analisa change order pada proyek perkerasan jalan (in Indonesian). STEMBI- Bandung Business School, 2013. ISBN 978-602-98733-4-4, p. 65-66.

[7] YANA, A. G. A., RUSDHI, H. A., WIBOWO, M. A. Analysis of factors affecting design changes in a construction project with partial least square (PLS). Procedia Engineering. 2015, 125, p. 40-45. ISSN 1877-7058.

[8] ALNUAMI, A. S., TAHA, R. A., MOHSIN, M. A., AL HARTHY, A. S. Causes, effect. benefit and remedies change order on public construction project in Oman. Journal of Construction Engineering and Management [online]. 2010, 136(5), p. 615-622. ISSN 0733-9364, eISSN 1943-7862. Available from: https://doi.org/10.1061/ ASCECO.1943-7862.0000154

[9] AKHAVIAN, R., BEHZADAN, A. H. An integrated data collection and analysis framework for remote monitoring and planning of construction operations. Advanced Engineering Informatics [online]. 2012, 26(4), p. 749-761. ISSN 1474-0346. Available from: http://dx.doi.org/10.1016/j.aei.2012.04.004

[10] TAYLOR, T. R., UDDIN, M., GOODRUUM, P. M., MCCOY, A., SHAN, Y. Change orders and lessons learned: knowledge from statistical analyses of engineering change orders on Kentucky highway projects. Journal of Construction Engineering and Management [online]. 2012, 138(12), p. 1360-1369. ISSN 0733-9364, eISSN 1943-7862. Available from: https://doi.org/10.1061/(ASCE)CO.1943-7862.0000550

[11] SHRESTA, P. P., SHRESTA, K. K., KANDIE, T. K. Effects of change orders on the cost and schedule of rural road maintenance projects. Journal of Legal Affairs and Dispute Resolution in Engineering and Construction [online]. 2017, 9(3), 04517010. ISSN 1943-4162, eISSN 1943-4170. Available from: https://doi.org/10.1061/(ASCE) LA.1943-4170.0000227

[12] HALWATURA, R. U., RANASINGHE, N. P. N. P. Causes of variation orders in road construction projects in Sri Lanka. International Scholarly Research Notices [online]. 2013. Available from: https//dx.doi.org/10.1155/2013/381670 
[13] DICKSON, O. D., GERRYSHOM, M., WANYONA, G. Variations in civil engineering construction projects in Kenya: causes and effects. International Journal of Engineering Research and Technology. 2015, 4(2), p. 1124-1129. ISSN 2278-0181

[14] HANNA, A. S., ISKANDAR, K. A. Quantifying and modeling the cumulative impact of change orders. Journal of Construction Engineering and Management [online]. 2017, 143(10), 04017076. ISSN 0733-9364, eISSN 1943-7862. Available from: https://doi.org/10.1061/(ASCE)CO.1943-7862.0001385

[15] SHRESTA, K. K., SHRESTA, P. P. Change orders on road maintenance contracts: causes and preventive measures. Journal of Legal Affairs and Dispute Resolution in Engineering and Construction [online]. 2019, 11(3), 04519009. ISSN 1943-4162, eISSN 1943-4170. Available from: https://doi.org/10.1061/(ASCE)LA.19434170.0000299

[16] WATY, M., SULISTIO, H. Identify the risk of road construction project change orders / Identifikasi risiko change order proyek konstruksi jalan (in Indonesian). Jurnal Muara Sains, Teknologi, Kedokteran dan Ilmu Kesehatan [online]. 2021, 5(1), p. 225-234. ISSN 2579-6402, eISSN 2579-6410. Available from: https://doi.org/10.24912/ jmstkik.v5i1.10094

[17] WATY, M., SULISTIO, H. Calculation of change orders for road projects in Banten / Perhitungan change order proyek jalan di Banten (in Indonesian). Jurnal Muara Sains, Teknologi, Kedokteran dan Ilmu Kesehatan [online]. 2020, 4(2), p. 211-220. ISSN 2579-6402, eISSN 2579-6410. Available from: https://doi.org/10.24912/ jmstkik.v4i2.6342

[18] BARRIE, D. S., PAULSON, B. C. Professional construction management. 3. ed. Civil Engineering Series. Singapore: Mc Graw-Hill Inc., 1992. ISBN 978-0070038899.

[19] EDWARD, P., WATY, M. Causes of change orders on road pavement projects / Penyebab change order pada proyek perkerasan jalan (in Indonesian). JMTS: Jurnal Mitra Teknik Sipil [online]. 2020, 3(1), p. 207-214. eISSN 2622-545X. Available from: https://doi.org/10.24912/jmts.v3i1.7012

[20] WATY, M., SULISTIO, H. Calculation of change order for road projects in Jakarta. IOP Conference Series: Materials Science and Engineering [online]. 2020, 1007(1), 012001. ISSN 1757-899X. Available from: https://doi.org/10.1088/1757-899X/1007/1/012001

[21] WATY, M., SULISTIO, H. Change orders and the risk of change orders on road projects in West Java / Change order dan risiko change order pada proyek jalan di Jawa Barat (in Indonesian). Paduraksa: Jurnal Teknik Sipil Universitas Warmadewa [online]. 2021, 10(1), p. 124-141. ISSN 2303-2693, eISSN 2581-2939. Available from: https://doi.org/10.22225/pd.10.1.2387.124-141.

[22] GARSON, G. D. Structural equation modeling, from statnotes: topics in multivariate analysis. 2009.

[23] NUNNALLY, J. C. Psychometric theory 3E. Tata McGraw-hill Education, 1994. ISBN 9780071070881.

[24] HAIR, J. F., BLACK, W. C., BABIN, B. J. ANDERSON, R. E., TATHAM, R. Multivariatedata analysis. Upper Saddle River, 2006. ISBN 9780130329295.

[25]HSIEH, T. Y., LU, S. T., WU, C. H. Statistical analysis of causes for change orders in metropolitan public works. International Journal of Project Management [online]. 2004, 22(8), p. 679-686. ISSN 0263-7863. Available from: https://doi.org/10.1016/j.ijproman.2004.03.005

[26] SOEHARTO, I. Project management from conceptual to operational. Jakarta: Erlangga, 1995. ISBN 9794115789.

[27 GILBREATH, R. D. Managing construction contracts: operational controls for commercial risks. Vol. 3. John Wiley and Sons, 1992. ISBN 05447159321.

[28] FINKE, M. R. A better way to estimate and mitigate disruption. Journal of Construction Engineering and Management [online]. 1998, 124(6), p. 490-497. ISSN 0733-9364, eISSN 1943-7862. Available from: https://doi.org/10.1061/(ASCE)0733-9364(1998)124:6(490) 